\title{
Journeys in the Roman East: Imagined and Real
}

\author{
Ed. by Maren R. Niehoff
}

[Reisen im Osten des Römischen Reichs: Fiktiv und Real.]

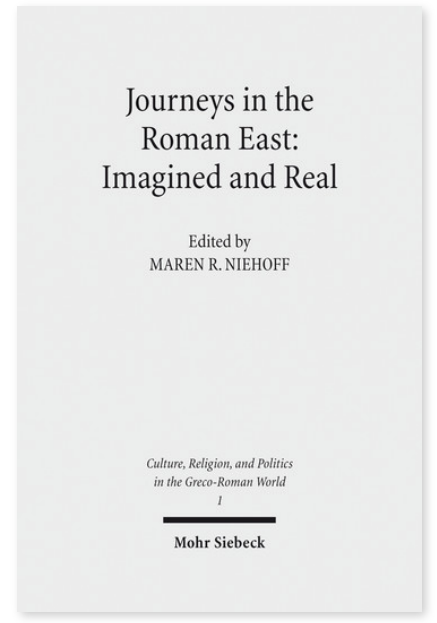

2017. XI, 440 Seiten. CRPG 1

ISBN 978-3-16-155858-0

DOI 10.1628/978-3-16-155858-0

eBook PDF $184,00 €$

ISBN 978-3-16-155111-6

Leinen $184,00 €$
Veröffentlicht auf Englisch.

Das Römische Reich ermöglichte Reisen in neuen Dimensionen und kreierte universale Diskurse, die lokale Identitäten in Frage stellten. Die Beiträge des vorliegenden Bandes untersuchen zum ersten Mal intellektuelle Aspekte von Reisen im Römischen Reich mit gleichwertigem Gewicht auf paganen, jüdischen und christlichen Autoren. Ein Team von Experten aus verschiedenen Fachbereichen fragt, wie Reisen erinnert wurden und welche Rolle sie in Konstruktionen von kulturellen Identitäten spielten.

Inhaltsübersicht

Maren Niehoff: Journeys on the Way to This Volume

\section{Imagined and Real Geography}

Ewen Bowie: Eastern Mediterranean Travel: The View from Aphrodisias and Hadrianoutherae - Janet Downie: The Romance of Imperial Travel in Aelius Aristides' Smyrna Orations - Nicola Zwingmann: The Account of a Journey in the Erôtes of [Pseudo] Lucian in the Context of Ancient Travel - Amit Gevaryahu: There and Back Again: A Journey to Ashkelon and its Intertexts in Yerushalmi Sanhedrin 4:6 (=Hagigah 2:2) - Benjamin Isaac: Virtual Journeys in the Roman Near East: Maps and Geographical Texts

\section{Reconstructing Encounters in Distant Places}

Froma Zeitlin: Apodêmia: The Adventure of Travel in the Greek Novel - Kendra Eshleman: Eastern Travel in Apollonius and the Apocryphal Acts of Thomas - Maren Niehoff: Parodies of Educational Journeys in Josephus, Justin Martyr and Lucian Jonathan Price: The Historiographical Vehicle of Lucian's Journey in Verae Historiae - Catherine Hezser: Strangers on the Road: Otherness, Identification and Disguise in Rabbinic Travel Tales of Late Roman Palestine

Between the Bodily and the Holy

Ian Rutherford: Concord and Communitas: Greek Elements in Philo's Account of Jewish Pilgrimage - Laura Nasrallah: Imposing Travelers. An Inscription from Galatia and the Journeys of the Earliest Christians - Sarit Kattan Gribetz: »Lead Me Forth in Peace«: The Wayfarer's Prayer and Rabbinic Rituals of Travel in the Roman World - Georgia Frank: Touching and Feeling in Late Antique Pilgrims' Narratives

Jesus' Travels from Different Perspectives

Reinhard Feldmeier: The Wandering Jesus: Luke's »Travel Narrative« - Richard Kalmin: Jesus' Descent to the Underworld in the Babylonian Talmud and in Christian Literature of the Roman East

\section{Destination Rome}

Danie/ Schwartz: »Going up to Rome« in Josephus' Antiquities - Knut Backhaus: From Disaster to Disclosure: The Shipwreck in the Book of Acts in Light of Greco-Roman Ideology - Yonatan Moss: „From Syria all the Way to Rome:« Ignatius of Antioch's Pauline Journey to Christianity

Maren R. Niehoff Geboren 1963; Ausbildung an der Hebräischen Universität Jerusalem, der Freien Universität in Berlin, Oxford University and Harvard University; seit 2014 Max Cooper Professor im Dept. für Jüdische Philosophie, Hebräische Universität Jerusalem.

https://orcid.org/0000-0002-0815-6929

Jetzt bestellen:

https://mohrsiebeck.com/buch/journeys-in-the-roman-east-imagined-and-real-9783161558580?no_cache=1 order@mohrsiebeck.com

Telefon: $+49(0) 7071-923-17$

Telefax: $+49(0) 7071-51104$ 